\title{
Isolation and Mycelial Growth of Diehliomyces microsporus: Effect of Culture Medium and Incubation Temperature
}

\author{
José Soares do Nascimento ${ }^{1}$ and Augusto Ferreira da Eira ${ }^{2}$ \\ ${ }^{1}$ Universidade Federal de Pelotas; Instituto de Biologia; Departamento de Microbiologia e Parasitologia; C.P. \\ 354; jose@ufpel.tche.br; 96010-900; Pelotas - RS - Brasil. ${ }^{2}$ Universidade Estadual Paulista; FCA; Departamento \\ de Produção Vegetal (Módulo de Cogumelos); C.P. 237; 18603-970; Botucatu - SP -Brasil
}

\begin{abstract}
The false truffle is one of the main problems in the production of the Agaricus brasiliensis in Brazil and the control of this fungal competitor has been rather difficult due to difficulties in the isolation and cultivation of this pathogen. This experiment was conducted in three stages, the first consisting of the isolation of Diehliomyces microsporus starting from portions of the fruiting body and through the ascospores suspension; second, D. microsporus cultivated in vitro at 15,20,25, 30 and $35^{\circ} \mathrm{C}$ in six different culture media (CSDA, OCDA, PCDA, ODA, PDA, CDA); third, D. microsporus was inoculated on sterilized compost for formation of the fruiting body. The colony formation from tissue of D. microsporus starting from portions of fruiting body was more efficient than germination of the ascospores. Compost medium (CDA) allowed a larger diameter of the $\mathrm{D}$. microsporus colony, followed by the medium made up of compost and potato mixture, favoring a denser composition. The largest mycelial growth speed of $\mathrm{D}$. microsporus occurred when the culture was incubated at 28 and $30^{\circ} \mathrm{C}$. Incubation temperatures lower than $15^{\circ} \mathrm{C}$ or above $35^{\circ} \mathrm{C}$ inhibited the mycelial growth of $\mathrm{D}$. microsporus completely. The fruiting bodies were obtained easily in sterilized compost and later inoculated along with mycelial competitor.
\end{abstract}

Key words: Agaricus brasiliensis, false truffle, culinary-medicinal mushrooms, culture media, mushroom disease, competitor

\section{INTRODUCTION}

Brazil is one of the main producers of the mushroom Agaricus brasiliensis (Murrill) S. Wasser, popularly denominated "Royal-sunAgaricus" in Brazil and Himematsutake in Japan. The growth of this mushroom started in Brazil in the 1990s, raising great interest in the Asian and North American markets due to its medicinal properties, especially its anti-oncogenic activity. A. brasiliensis is grown in the hot months, especially during the spring, summer and autumn. Because it is a mushroom of hot climate and low technology systems, those conditions favor the emergence of pest, such flies, nematodes and colembolas. The bacteria and mainly the fungi act as competitors or causes of diseases, resulting in low yields (Nascimento and Eira, 2003b; Nascimento, 2003).

The problems that affect the yields of $A$. brasiliensis are countless because it is a recent culture. Lately, the appearance of false truffle has been suggested (Diehliomyces microsporus Diehl and Lamb. Gilkey) as a major problem for the cultivation, mainly when the appropriate technology is not used (Nascimento and Eira, 2001).

\footnotetext{
${ }^{*}$ Author for correspondence
} 
In 2000, farmers from the Brazilian states of São Paulo and Paraná suggested the presence of structures similar to deformed origins, commonly called "popcorns", during the fruiting period. When these structures appear, A. brasiliensis does not produce and more severe recurrences take place in subsequent cultivations. After identification studies, the contamination was found to be caused by D. microsporus (Nascimento and Eira, 2001). This fungus is considered as of the most critical competitor in the cultivation of $A$. brasiliensis (Nascimento and Eira, 2003a).

The isolation and the culture conditions for cultivation of D. microsporus have been described by many authors. From its first isolation, accomplished by Diehl and Lambert (1930), it was deduced that oats medium and soil extract favored the mycelial growth. Zaayen and Pol-Luiten (1977 and 1978) obtained the best mycelial growth in malt and potato medium; however, this growth demonstrated an instability in the formation of the colony. There have been several studies in relation to incubation temperature. According to Bisset et al. (1982), D. microsporus needs high temperatures $\left(22-30^{\circ} \mathrm{C}\right)$ for germination of ascospores; however, the mycelium also grows at low temperatures $\left(16^{\circ} \mathrm{C}\right)$, but the ideal temperature for the mycelial growth is $26^{\circ} \mathrm{C}$. Sharma (1998) submitting the ascospores to $45^{\circ} \mathrm{C}$, followed by incubation at $33^{\circ} \mathrm{C}$, reduced the germination of ascospores significantly (4\%) when compared in relation to incubation at $27^{\circ} \mathrm{C}$. The lowest temperature presented $70 \%$ germination after a 72 $\mathrm{h}$ incubation period. Thus, this research had as objectives: establish a methodology for the isolation of $D$. microsporus; to study the cultivation conditions for $D$. microsporus (medium and temperatures) and to obtain ascostroms of $D$. microsporus on sterilized composed.

\section{MATERIAL AND METHODS}

\section{Isolation of $\boldsymbol{D}$. microsporus}

The ascostroms of the false truffle (competitor fungus) were collected from $A$. brasiliensis cultivations. In aseptic conditions, the fungus was isolated on PDA and CDA media. For obtaining PDA medium, $150 \mathrm{~g}$ potato was added to $1 \mathrm{~L}$ distilled water and then boiled for 15 minutes. The medium was filtered in gauze and $10 \mathrm{~g}$ liquid dextrose, $15 \mathrm{~g}$ agar was added and the volume for $1 \mathrm{~L}$ was completed with distilled water. This medium was sterilized at $121^{\circ} \mathrm{C}$ for 20 minutes. The same procedure was followed with CDA medium, in which $20 \mathrm{~g}$ of dry and ground compost prepared for the cultivation of A. brasiliensis was used. The culture media were poured in to Petri dishes $(90 \mathrm{~mm} \times 15 \mathrm{~mm})(15 \mathrm{~mL} /$ plate).

The treatments consisted of two different ways of D. microsporus isolation with 10 replications. For both, ascostroms were used within $24 \mathrm{~h}$ after collection. For the first isolation form, the ascostroms were opened manually in aseptic conditions to remove the inner mass with a nickelchrome needle in the shape of an "L" and transferred to a central surface medium. The other isolation form consisted of softening the inner mass of several fruiting bodies, which was thereupon diluted in sterile water. The suspension was filtered throng sterilized cotton wool to remove asci and mycelial fragments, thus obtaining the ascospores. The suspension of spores previously prepared was on the surface of the medium, at a concentration of $4.8 \times 10^{3}$ ascospores $\mathrm{mL}^{-1}$. Incubation was performed in Petri dishes at $25^{\circ} \mathrm{C}$ in the absence of light for 12 days. The evaluation consisted of estimating the number of colonies formed by D. microsporus and the index of contamination for other microorganisms.

In vitro cultivation condition for $D$. microsporus A culture of D. microsporus (DMI 00/01) was multiplied in other culture media (Table 1) on Petri dishes $(90 \mathrm{~mm} \times 15 \mathrm{~mm})$. These culture media (Table 1) were prepared from the extracts. After distribution the media in Petri dishes, the culture was transferred and the plates were incubated at $25^{\circ} \mathrm{C}$. After mycelial growth, $0.5 \mathrm{~cm}$ diameter culture discs were transferred to the center of other Petri dishes which contained the same culture medium and incubated according to the treatments. The treatments consisted of the interaction of the temperature $\left(15,20,25,30\right.$ and $\left.35^{\circ} \mathrm{C}\right)$ and the culture medium (Table 1) in a completely randomized factorial design with seven replications. The evaluation consisted of daily measurements of mycelium growth (colony diameter) of D. microsporus.

\section{Cultivation of $D$. microsporus on sterilized compost}

Parts of the mycelium obtained after the isolation of $D$. microsporus were transferred to sterilized compost and arranged in flasks with $250 \mathrm{~g}$ of humid compost in order to be cultivated until 
fruiting bodies production in 10 replications. The top of the flasks was sealed with cotton to enable gaseous changes with the environment and incubated at $25^{\circ} \mathrm{C}$ in the absence of light for 12 days. After the mycelial growth, the fruiting bodies of $D$. microsporus were observed in an optical microscope (in sections stained with lactofenol and Amann's blue).

Table 1 - Composition of medium used on Diehliomyces microsporus cultivation in vitro.

\begin{tabular}{|c|c|}
\hline Medium & Composition \\
\hline CSDA & $\begin{array}{l}10 \mathrm{~g} \text { compost (after phase } \mathrm{II}) \text { and } 10 \mathrm{~g} \text { soil were added to } 1 \mathrm{~L} \text { distilled water, boiled for } 15 \mathrm{~min} \text { and, to } \\
\text { the resulting liquid extract, } 10 \mathrm{~g} \text { dextrose and } 15 \mathrm{~g} \text { agar were added. After that, the volume was made } \\
1 \mathrm{~L} \text { was completed with distilled water. The medium was sterilized at } 121^{\circ} \mathrm{C} \text { for } 30 \text { minutes. }\end{array}$ \\
\hline OCDA & $\begin{array}{l}10 \mathrm{~g} \text { oat and } 10 \mathrm{~g} \text { of compost were added to } 1 \mathrm{~L} \text { distilled water, boiled for } 15 \mathrm{~min} \text { and } 10 \mathrm{~g} \text { dextrose and } \\
15 \mathrm{~g} \text { agar were added. The volume was then made } 1 \mathrm{~L} \text { with distilled water. The medium was sterilized } \\
\text { at } 121^{\circ} \mathrm{C} \text { for } 30 \mathrm{~min} \text {. }\end{array}$ \\
\hline ODA & $\begin{array}{l}20 \mathrm{~g} \text { of oat was added in } 1 \mathrm{~L} \text { distilled water, boiled for } 15 \mathrm{~min} \text { and } 10 \mathrm{~g} \text { dextrose and } 15 \mathrm{~g} \text { agar were } \\
\text { added to the liquid extract. Subsequently, the volume of } 1 \mathrm{~L} \text { was made with distilled water. The } \\
\text { medium was sterilized at } 121^{\circ} \mathrm{C} \text { for } 30 \mathrm{~min} \text {. }\end{array}$ \\
\hline PDA & $\begin{array}{l}150 \mathrm{~g} \text { chopped potato was added to a liter of distilled water, boiled for } 15 \mathrm{~min} \text { and } 10 \mathrm{~g} \text { dextrose and } \\
15 \mathrm{~g} \text { agar were added to the liquid extract. Then the volume for } 1 \mathrm{~L} \text { was made with distilled water. The } \\
\text { medium was sterilized at } 121^{\circ} \mathrm{C} \text { for } 30 \mathrm{~min} \text {. }\end{array}$ \\
\hline PCDA & $\begin{array}{l}75 \mathrm{~g} \text { chopped potato and } 10 \mathrm{~g} \text { compost were added to } 1 \mathrm{~L} \text { distilled water, boiled for } 15 \mathrm{~min} \text { and } 10 \mathrm{~g} \\
\text { dextrose and } 15 \mathrm{~g} \text { agar were added to the liquid extract. After, the volume for } 1 \mathrm{~L} \text { was made with } \\
\text { distilled water. The medium was sterilized at } 121^{\circ} \mathrm{C} \text { for } 30 \mathrm{~min} \text {. }\end{array}$ \\
\hline $\mathrm{CDA}$ & $\begin{array}{l}20 \mathrm{~g} \text { compost was added to } 1 \mathrm{~L} \text { distilled water, boiled for } 15 \mathrm{~min} \text { and } 10 \mathrm{~g} \text { dextrose and } 15 \mathrm{~g} \text { agar were } \\
\text { added to liquid extract. The volume for } 1 \mathrm{~L} \text { was made with distilled water. The medium was sterilized } \\
\text { at } 121^{\circ} \mathrm{C} \text { for } 30 \mathrm{~min} \text {. }\end{array}$ \\
\hline
\end{tabular}

\section{RESULTS AND DISCUSSION}

\section{Isolation of $\boldsymbol{D}$. microsporus}

False truffle contaminations became evident during the cultivation of $A$. brasiliensis by the formation of ascostroma of D. microsporus. Usually signs of the false truffle were observed in the final phase of mycelial growth or more commonly during the cropping of the mushrooms (Fig. 1). The young ascostroma had firmer texture and when they ripened they were fragile and desintegrate. At this point, spores were disseminated through air.

When the ascospores were separated from the ascostroma, they had a low percentage of germination and when the isolation was made starting from portions of the recently picked young ascostrom, there was a largest colony formation (Table 2). In view of these results, it was believed that the colony formed the $D$. microsporus fruiting bodies were due to vegetative propagation (asexual reproduction). In this type of isolation, contamination also occurred and the results were not always positive, because it depended on the life time of ascostroma and on casing soil and compost that were involved during their formation. The ascostroma is kidney-shaped and formed by anastomosis, keeping the incoming particles from the external casing soil. Also, during the growth phase of ascostroma, those closer are joined, forming a larger structure. When the ascostroma were washed with either water or antiseptic, they became more fragile for manipulation and the propagation rate decreased. Therefore, in this experiment, the result of isolation was more satisfactory when the ascostroma had been recently picked and not washed, taking portions of the ascostroma and transferring them into the compost medium (CDA). 

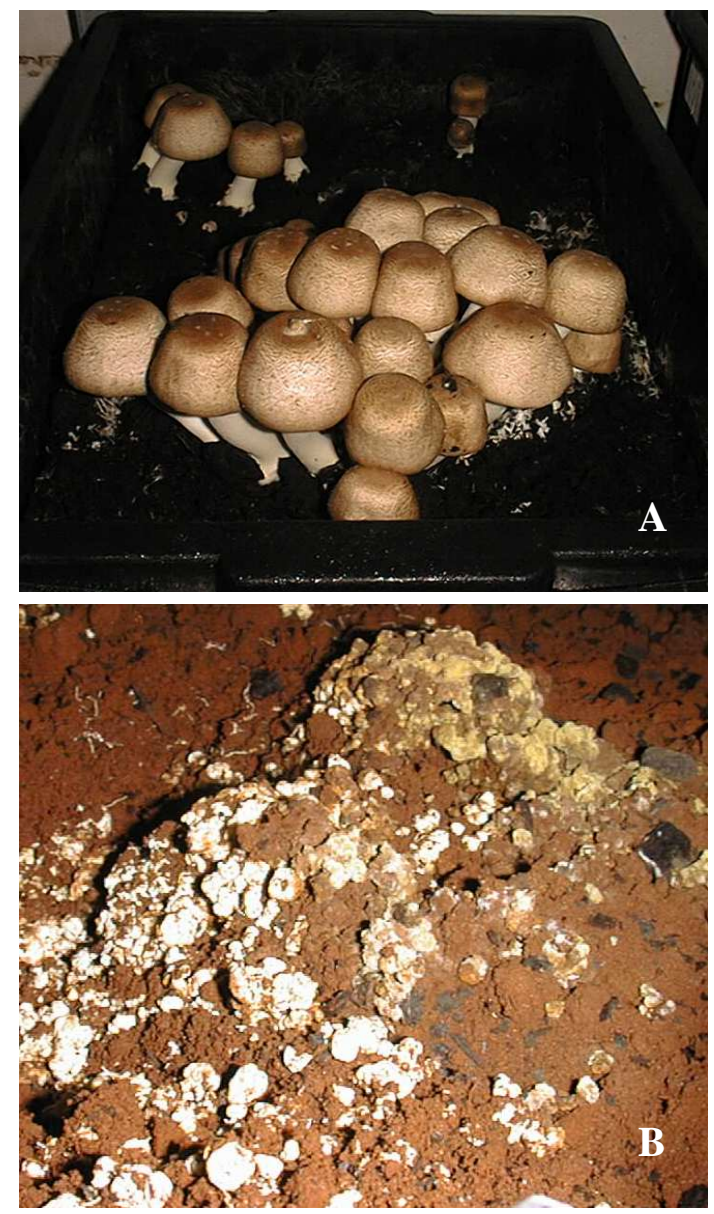

Figure 1 - Fruiting bodies of the Agaricus brasiliensis (A) and Diehliomyces microsporus (B) in Brazil.

Table 2 - Formation of colonies and contaminations starting from Diehliomyces microsporus (DMI) isolation in vitro

\begin{tabular}{lccc}
\hline Treatments & Colony formed (DMI) & Contamination & No growth \\
\hline & 60 & $(\%)$ & 30 \\
Ascostroma portion & 20 & 10 & 50 \\
Ascospores suspension & & 30 & \\
\hline
\end{tabular}

\section{In vitro cultivation conditions of the $D$.} microsporus

The average mycelial growth data of in vitro cultivation the $D$. microsporus in different culture media and temperatures are shown in Table 3. At 15 and $35^{\circ} \mathrm{C}$, there was no colony formation in any of the culture media tested. The incubation at 20 , 25 and $30^{\circ} \mathrm{C}$ on the CDA media (compost based) provided a significantly larger diameter of the colony than any other media. This referred mainly to the starch based ones (ODA and PDA), in which the growth had its peak at $30^{\circ} \mathrm{C}$. The mixed media, made up of the mixture of compost with other such materials as oats, soil or potato favored the mycelial growth of $D$. microsporus. On the other hand, at 20,25 and $30^{\circ} \mathrm{C}$, the culture media that favored the largest growth, such as CDA, CSDA and OCDA yielded a less dense mycelium, with predominance of fluffy mycelium, while PCDA favored the mycelial occurrence with 
largest density (visualized, but not quantified data) and a colony with a smaller diameter.

Diehl and Lambert (1930) tested several combinations of media from wheat, oat, rice, corn, soil extract to manure extract in the cultivation of D. microsporus, obtaining better growth for oat and soil extract based media. That was partly different from the results obtained in this experiment, because the oat based media presented a significantly smaller mycelial growth. However, when testing several culture media for mycelial growth of D. microsporus, Zaayen and Pol-Luiten (1977) obtained better regular growth in the maltagar and PDA media. Nevertheless, in most cases, there was formation of sector and fluffy mycelium, what made the measurements difficult. In the mixed medium made up of potato and compost for A. brasiliensis, this did not happen and there was a typical radial growth.

A critical point in the cultivation of $A$. brasiliensis, in relation to $D$. microsporus was that both presented faster growth in the same temperature range, differently from the $A$. bisporus, in which the temperature could drop below $18^{\circ} \mathrm{C}$ during the body fruiting phase, limiting the progression of the false truffle in this phase of the cultivation.

The diameter of the colony of $D$. microsporus in the several culture media and incubation temperature can be expressed through a sixth degree polynomial equation, with a peak at around of $30^{\circ} \mathrm{C}$ (Fig. 2).

The CDA media yielded a largest peak of mycelial growth of the D. microsporus, as showed in Table 3. In all the media, the null diameter at $15^{\circ} \mathrm{C}$ increased gradually according to a temperature increase from 20 to $25^{\circ} \mathrm{C}$. It reached its maximum peak at around $30^{\circ} \mathrm{C}$, after which it decreased quickly when incubated at $35^{\circ} \mathrm{C}$, when the colony diameter was null again. Different results were presented by Zaayen and Pol-Luiten (1977), who obtained maximum growth of $D$. microsporus at $26^{\circ} \mathrm{C}$. The estimated temperatures by the regression equation would result in the maximum peaks of colony diameter in the respective media are: $29.7^{\circ} \mathrm{C}$ (CSDA), $31.0^{\circ} \mathrm{C}$ (PCDA), $28.5^{\circ} \mathrm{C}$ (OCDA), $29.3^{\circ} \mathrm{C}$ (CDA), $30.8^{\circ} \mathrm{C}$ (PDA) and $29.8^{\circ} \mathrm{C}$ (ODA).

Table 3 - Colony diameter $(\mathrm{cm})$ of Diehliomyces microsporus cultivated in different culture media in vitro and incubated at temperatures of $15,20,25,30,35^{\circ} \mathrm{C}$ for 7 days.

\begin{tabular}{|c|c|c|c|c|c|}
\hline \multirow[t]{2}{*}{ Culture medium } & \multicolumn{5}{|c|}{ Incubation temperature, ${ }^{\circ} \mathrm{C}$} \\
\hline & 15 & 20 & 25 & 30 & 35 \\
\hline CSDA & $0 \mathrm{a}$ & $1.06 \mathrm{c}$ & $2.03 \mathrm{~b}$ & $3.35 \mathrm{~b}$ & $0 \mathrm{a}$ \\
\hline PCDA & $0 \mathrm{a}$ & $0.73 \mathrm{~d}$ & $1.98 \mathrm{~b}$ & $2.64 \mathrm{c}$ & $0 \mathrm{a}$ \\
\hline OCDA & $0 \mathrm{a}$ & $1.54 \mathrm{~b}$ & $2.61 \mathrm{a}$ & $3.35 \mathrm{~b}$ & $0 \mathrm{a}$ \\
\hline CDA & $0 \mathrm{a}$ & $2.50 \mathrm{a}$ & $2.68 \mathrm{a}$ & $3.82 \mathrm{a}$ & $0 \mathrm{a}$ \\
\hline PDA & $0 \mathrm{a}$ & $0.64 \mathrm{ed}$ & $1.34 \mathrm{c}$ & $2.38 \mathrm{~cd}$ & $0 \mathrm{a}$ \\
\hline ODA & $0 \mathrm{a}$ & $0.33 \mathrm{e}$ & $1.59 \mathrm{c}$ & $2.33 \mathrm{~d}$ & $0 \mathrm{a}$ \\
\hline $\mathrm{CV} \%$ & - & 17.69 & 8.63 & 6.29 & - \\
\hline DMS & 0 & 0.32 & 0.28 & 0.3 & 0 \\
\hline
\end{tabular}

Tukey's test: means followed by different letters in the column are significantly different at $5 \%$.

CSDA: compost-soil-dextrose-agar; PCDA: potato-compost-dextrose-agar; OCDA: oat-compost-dextrose-agar; CDA: compostdextrose-agar; PDA: potato-dextrose-agar; ODA: oat-dextrose-agar. 

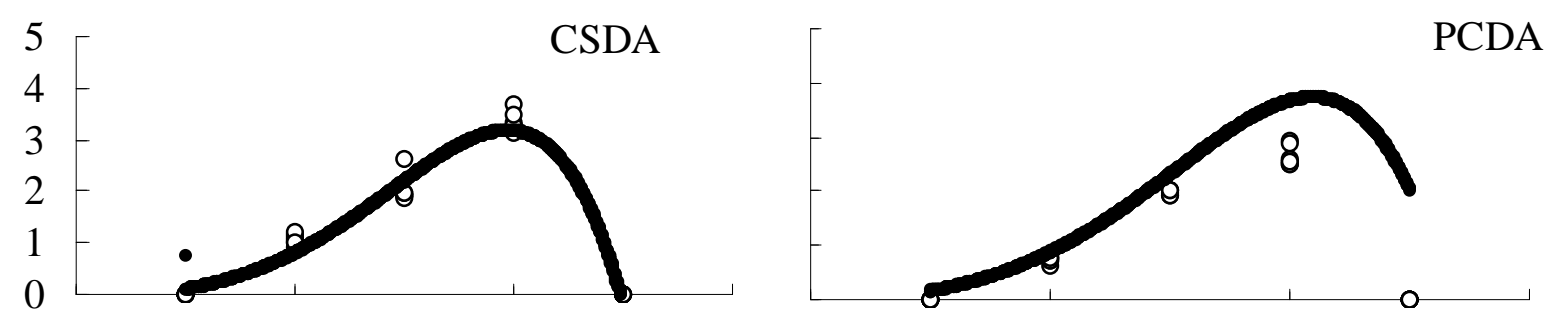

$\mathrm{y}=-0.0000000007-0.0000000122 \mathrm{x}-0.000000181 \mathrm{x}^{2}-$ $0.0000023 \mathrm{x}^{3}-0.00002 \mathrm{x}^{4}+0.00000218 \mathrm{x}^{5}-$ $0.000000046 \mathrm{x}^{6}$

$$
\mathrm{R}^{2}=0.97
$$

$\mathrm{y}=-0.00000000057-0.000000009 \mathrm{x}-0.00000013 \mathrm{x}^{2}-$ $0.0000016 \mathrm{x}^{3}-0.000015 \mathrm{x}^{4}+0.0000017 \mathrm{x}^{5}-$ $0.000000036 \mathrm{x}^{6}$ $\mathrm{R}^{2}=0.99$
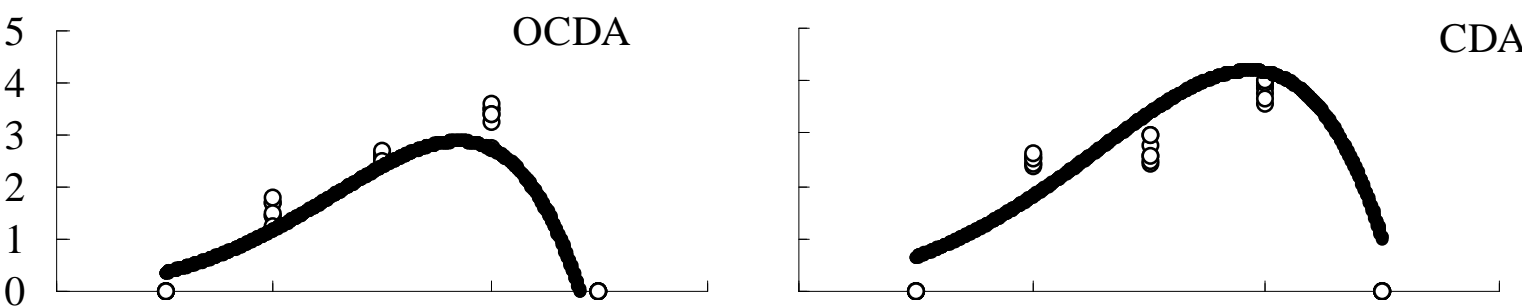

$\mathrm{y}=-0.000000000099-0.0000000016 \mathrm{x}$

$-0.000000024 \mathrm{x}^{2}-0.0000003 \mathrm{x}^{3}-$

$0.0000026 \mathrm{x}^{4}+0.0000011 \mathrm{x}^{5}-0.00000003 \mathrm{x}^{6}$

$\mathrm{R}^{2}=0.96$

$\mathrm{y}=0.00000000044+0.000000007 \mathrm{x}+0.0000001 \mathrm{x}^{2}+$ $0.0000013 x^{3}+0.000012 x^{4}+0.00000034 x^{5}-$

$0.000000019 x^{6}$

$\mathrm{R}^{2}=0.89$
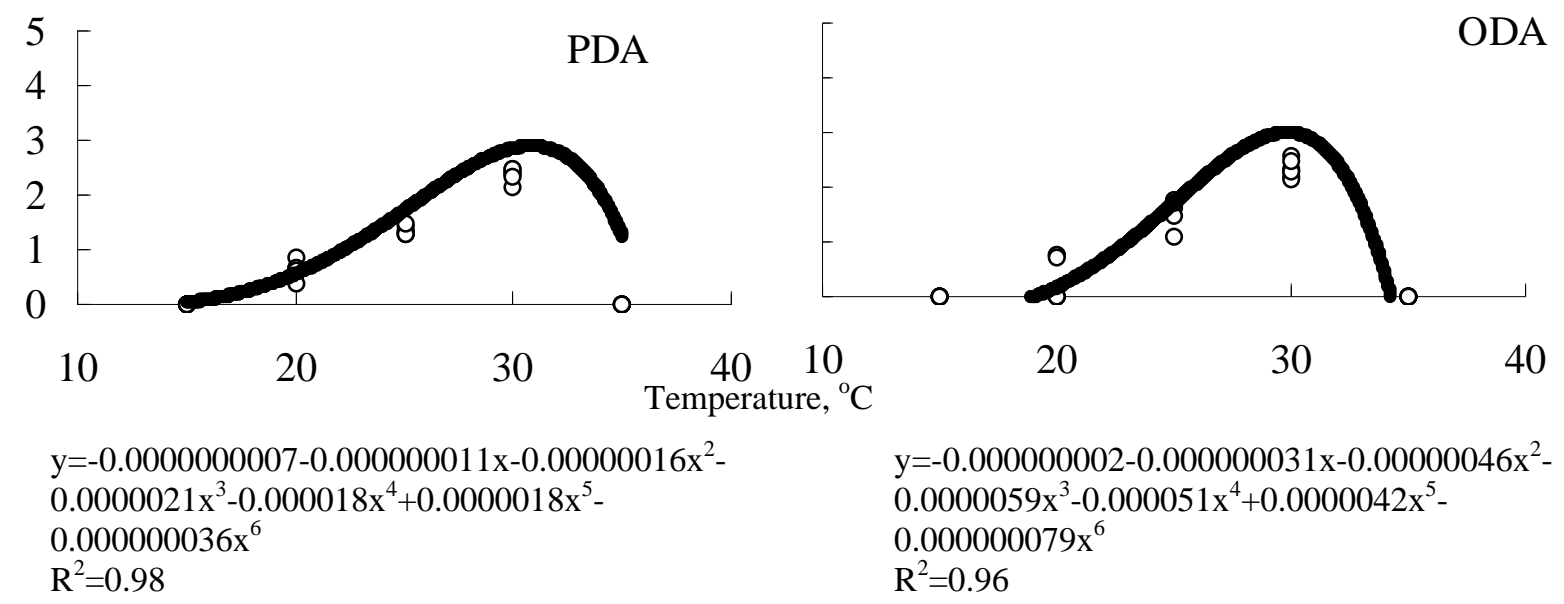

$\mathrm{y}=-0.0000000007-0.000000011 \mathrm{x}-0.00000016 \mathrm{x}^{2}-$ $0.0000021 \mathrm{x}^{3}-0.000018 \mathrm{x}^{4}+0.0000018 \mathrm{x}^{5}-$

$\mathrm{R}^{2}=0.98$

$\mathrm{y}=-0.000000002-0.000000031 \mathrm{x}-0.00000046 \mathrm{x}^{2}-$ $0.0000059 \mathrm{x}^{3}-0.000051 \mathrm{x}^{4}+0.0000042 \mathrm{x}^{5}-$ $0.000000079 \mathrm{x}^{6}$ $\mathrm{R}^{2}=0.96$

Figure 2 - Colony diameter of Diehliomyces microsporus in different in vitro culture media incubated at temperatures of $15,20,25,30,35^{\circ} \mathrm{C}$ for 7 days.

CSDA: compost-soil-dextrose-agar; PCDA: potato-compost-dextrose-agar; OCDA: oat-compost-dextrose-agar; CDA: compost-dextrose-agar; PDA: potato-dextroseagar; ODA: oat-dextrose-agar. 
Cultivation of D. microsporus in sterilized compost

The fruiting bodies of D. microsporus were checked approximately 30 days after the inoculation of the prepared compost for the cultivation of $A$. brasiliensis. This medium was sterilized and inoculated with the competitor only (Fig. 3A). The fruiting bodies of the false truffle were shown to be similar to a great amount of deformed pin or "popcorn-like" structures, as it was called by the growers.

Biotic and abiotic factors such as temperature, humidity, presence of the host or other microorganisms, are still not certain. They can favor the fruiting bodies of the false truffle in the cultivation of mushrooms or even the ones that they can contribute in the performance of the fungus as a parasite in the system.

When the D. microsporus was inoculated in the sterilized compost, the fruiting bodies of $D$. microsporus occurred independently of the presence of the A. brasiliensis (Fig. 3A). Parallel to this, during the experiment, the farmers of $A$. brasiliensis observed ascostroma of the false truffle before placement of the casing layer (Fig. $3 \mathrm{~B}$ ), and the most significant incidence of the ascostroma occurred during, or after the initial phase of fruiting bodies of $A$. brasiliensis. When grown in transparent plastic bags, a regular procedure in mushroom farms, the largest ascostroma concentration was observed at the edge of the plastic. Initially, in the surface of the casing layer, there appear cracks where a lot of the ascostroma are concentrated in the interface compost/casing, usually with a decrease or absence of production of $A$. brasiliensis (Fig. 3C). These observations also apply to the cultivation of A. bisporus and A. bitorquis, according to Kligman (1944), Zaayen and Pol-Luiten (1978), Sharma (1998).
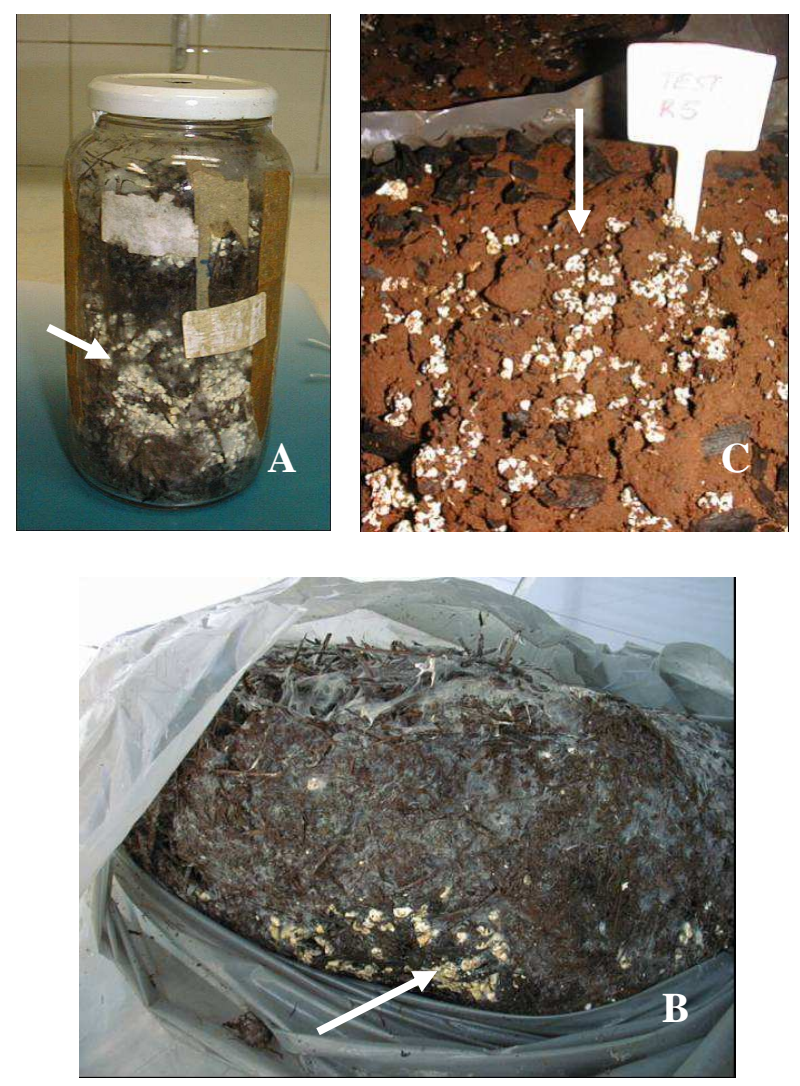

Figure 3 - Fruiting bodies of Diehliomyces microsporus (indicated by the arrows) with material incubated at the laboratory and supplied by the farmers of Agaricus brasiliensis (bags). (A) ascostroma in sterilized compost incubated at $28^{\circ} \mathrm{C}$ for 35 days; (B) fruiting bodies in the compost before the casing with approximately 30 days; (C) superficial blooming of the ascostroma in the casing soil. 
The ascostroma of D. microsporus presented variations in size from 5 to $30 \mathrm{~mm}$ in diameter, had cephalic forms, initially from a yellowish-white coloration to brown in the maturation phase (Fig. 4A). When they grew very closely some ascostroma joined, forming larger and deformed structures (Fig. 4B). These characteristics confirmed the observations made by Diehl and Lambert (1930), Kligman (1944), Zaayen and PolLuiten (1977), Wood and Fletcher (1991), Yadav et al. (2000), during the cultivations of A. bisporus and $A$. bitorquis.
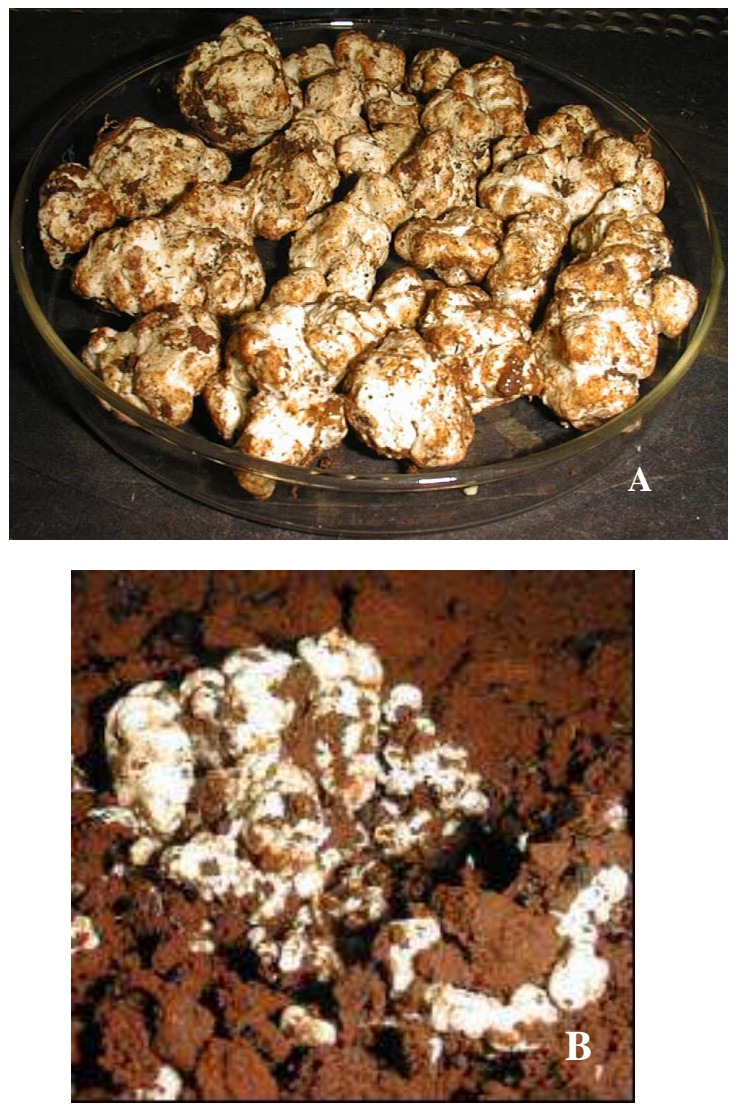

Figure 4 - Ascostroma of Diehlioyces microsporus: (A): ascostroma collected in Petri dish; (B) ascostroma union on casing soil.

\section{CONCLUSIONS}

The isolation of $D$. microsporus from fragments of recently collected ascostroma was more efficient than the germination of the ascospores. The culture media made from a compost base (CDA) provided largest colony diameter of the $D$. microsporus, followed by the media made up of the compost and potato mixture, favoring a denser mycelia. The maximum growth speed of $D$. microsporus occurred when the culture was incubated between 28 and $30^{\circ} \mathrm{C}$. Low $\left(15^{\circ} \mathrm{C}\right)$ or high $\left(35^{\circ} \mathrm{C}\right)$ incubation temperatures completely inhibited the mycelial growth of $D$. microsporus.
The fruiting bodies of $D$. microsporus occurred before the placement of the casing layer, and during the phase of fruiting bodies of $A$. brasiliensis.

\section{ACKNOWLEDGMENTS}

FAPESP (Fundação de Amparo à Pesquisa do Estado de São Paulo) and CAPES (Coordenação de Aperfeiçoamento de Pessoal de Nível Superior) supported this research. 


\section{RESUMO}

A falsa trufa está sendo um dos principais problemas na produção do Agaricus brasiliensis cultivado no Brasil e o controle deste fungo competidor tem sido difícil, devido às dificuldades encontradas no isolamento e cultivo do patógeno. Este experimento foi conduzido em três etapas, sendo a primeira constituída pelo isolamento de Diehliomyces microsporus a partir de porções do ascostroma e através da suspensão de ascósporos; a segunda, o cultivo in vitro de $D$. microsporus nas temperaturas de $15,20,25,30$ e $35^{\circ} \mathrm{C}$ e em seis meios de cultura (CTDA, ACDA, BCDA, ADA, BDA e CDA) e a terceira pela inoculação de $D$. microsporus no composto (pasteurizado, composto esterilizado e composto esterilizado com camada de cobertura) para formação dos ascostromas. O isolamento de $D$. microsporus a partir de fragmentos do ascostroma recém coletado foi mais eficiente do que a germinação dos ascósporos; o meio de cultura à base de composto (CDA) proporcionou maior diâmetro da colônia de $D$. microsporus, seguido pelo meio constituído da mistura de composto e batata, favorecendo um micélio mais denso; a maior velocidade de crescimento de D. microsporus ocorreu quando a cultura foi incubada entre 28 e $30^{\circ} \mathrm{C}$; temperaturas de incubação menor que $15^{\circ} \mathrm{C}$ ou a acima de $35^{\circ} \mathrm{C}$ inibiu completamente o crescimento micelial de $D$. microsporus; a obtenção de frutificação de $D$. microsporus foi facilmente obtida em composto esterilizado e posteriormente inoculado com o competidor.

\section{REFERENCES}

Bisset, P.G., Colhoun, J., Gandy, D.G. 1982. Germination of Diehliomyces microsporus ascospores and determination of their thermal death point. Transation of the British Mycological Society, 78, 3, 540-542.

Diehl, W.W., Lambert, E.B., 1930. A new truffle in beds of cultivated mushrooms. Mycologia, 22, 223226.
Kligman, A.M. 1944. Conthol of the truffle in beds of the cultivated mushroom. Phytopathology, 34, 376384.

Nascimento, J.S. 2003. Etiologia, controle e demanda de energia na prevenção da falsa trufa (Diehliomyces microsporus) em cultivos de Agaricus blazei Botucatu, 115p. Tese (Doutorado em Agronomia/Energia na Agricultura) - Faculdade de Ciências Agronômicas, Universidade Estadual Paulista.

Nascimento, J.S., Eira, A.F. 2001. Ocorrência e prejuízos da falsa trufa (Diehliomyces microsporus) em cultivo do Agaricus blazei Murrill. Congresso Brasileiro de Micologia, 3, Águas de Lindóia. Resumos... São Paulo: Sociedade Brasileira de Micologia, 2001. p.37.

Nascimento, J.S., Eira, A.F. 2003a. Occurrence of false truffle (Diehliomyces microsporus Gilkey) and damage on the Himematsutake medicinal mushroom (Agaricus brasiliensis S. Wasser et al.). Int. J. Med. Mushr., 5, 1, 87-94.

Nascimento, J.S., Eira, A.F. 2003b. Doenças e competidores do Agaricus blazei. In: Eira, A.F. cultivo do "cogumelo-do-sol" (Agaricus blazei (Murrill) ss. Heinemann). Viçosa: Aprenda Fácil, p.221-249.

Sharma, V.P. 1998. Biology and management of false truffle (Diehliomyces microsporus) during cultivation of Agaricus spp. Mushr. Res., 7, 1, 1-12.

Zaayen, A. Van, Pol-Luiten, B. Van Der. 1977. Heat resistance, biology and prevention of Diehliomyces microsporus in crops of Agaricus species. J. Pl. Path., 83, 221-240.

Zaayen, A. Van, Pol-Luiten, B. Van Der. 1978. Heat resistance, some biological aspects and prevention of false truffle (Diehliomyces microsporus). In: Maher, M.J. (Ed.) Science and cultivation of edible fungi. Rotterdam: Balkema, 2, 319-336.

Wood, M.W., Fletcher, J.T. 1991. The occurrence of ascocarps of Diehliomyces microsporus, the cause of false truffle disease. Mushrooms Science XII, 1, 379384.

Yadav, M.C., Dhar, B.L., Verma, R. N. 2000. Breeding studies on development of high yielding and quality hybrids of Agaricus bitorquis. Mushrooms Science $X V, 1,299-304$.

Received: October 10, 2005; Revised: April 20, 2006; Accepted: March 20, 2007. 
PÁGINA

EM

BRANCO 